\title{
Evaluation of titanium implants with surface modification by laser beam. Biomechanical study in rabbit tibias
}

\section{Rafael Silveira Faeda(a) Hewerson Santos Tavares(a) Rafael Sartori(a) \\ Antonio Carlos Guastaldi(b) Elcio Marcantonio Jr. (c)}

(a) Doctorate Student; (c)PhD, Assistant Professor - Department of Diagnosis and Surgery, School of Dentistry of Araraquara, São Paulo State University (UNESP), Araraquara, SP, Brazil.

(b) PhD Professor, Department of Biomaterials, Chemistry Institute, São Paulo State University (UNESP), Araraquara, SP, Brazil.

\begin{abstract}
The purpose of the present study was to evaluate, using a biomechanical test, the force needed to remove implants with surface modification by laser (Nd:YAG) in comparison with implants with machined surfaces. Twenty-four rabbits received one implant with each surface treatment in the tibia, machined surface (MS) and laser-modified surface (LMS). After 4, 8 and 12 weeks of healing, the removal torque was measured by a torque gauge. The surfaces studied were analyzed according to their topography, chemical composition and roughness. The average removal torque in each period was $23.28,24.0$ and $33.85 \mathrm{Ncm}$ for MS, and 33.0, 39.87 and $54.57 \mathrm{Ncm}$ for LMS, respectively. The difference between the surfaces in all periods of evaluation was statistically significant $(\mathrm{p}<0.05)$. Surface characterization showed that a deep and regular topography was provided by the laser conditioning, with a great quantity of oxygen ions when compared to the MS. The surface micro-topography analysis showed a statistical difference $(\mathrm{p}<0.01)$ between the roughness of the LMS $\left(R_{a}=1.38 \pm 0.23 \mu \mathrm{m}\right)$ when compared to that of the MS $\left(R_{a}=0.33 \pm 0.06 \mu \mathrm{m}\right)$. Based on these results, it was possible to conclude that the LMS implants' physical-chemical properties increased bone-implant interaction when compared to the MS implants.
\end{abstract}

Descriptors: Dental implants; Lasers; Osseointegration.
Corresponding author:

Elcio Marcantonio Junior

Faculdade de Odontologia de Araraquara

(UNESP) - Disciplina de Periodontia

Rua Humaitá, 1680

Araraquara - SP - Brazil

CEP: 14801-093

E-mail: elcioir@foar.unesp.br 


\section{Introduction}

Oral rehabilitation by means of endosseous dental implants has gained importance in clinical practice. Local bone quality and systemic implications on the oral healing condition have a direct role in the success of dental implant therapy. ${ }^{1,2}$

In order to improve both quantity and quality of the bone-implant interface in face of adverse conditions, and to accelerate the osseointegration, numerous implant surface modifications have been used. ${ }^{3}$ The surface characteristics of titanium implants have been modified by additive methods, such as titanium ${ }^{4}$ and hydroxyapatite plasma spray, ${ }^{5}$ as well as by subtractive methods, such as acid etching, ${ }^{6}$ acid etching associated with sandblasting by either $\mathrm{AlO}_{2}$ or $\mathrm{TiO}_{2},{ }^{7}$ and laser ablation. ${ }^{3,8,9}$

The laser ablation technology for surfaces preparation already has numerous industrial applications. This process results in titanium surface microstructures with greatly increased hardness, corrosion resistance, a high degree of purity with a standard roughness and thicker oxide layer. ${ }^{8,10}$ Biological studies evaluating the role of titanium ablation topography and chemical properties showed the potential of the grooved surface to orientate osteoblast cell attachment and control the direction of ingrowth. ${ }^{11-13}$

Based on the potential of this surface treatment to improve bone-implant interaction, the purpose of the present study was to evaluate the influence of laser surface modification on the retention of dental implants, when compared to that of machined implants.

\section{Material and Methods Implant surface preparation}

Forty-eight commercially pure, titanium dental implants (Titanium Fix ${ }^{\circledR}$, AS Technology, São José dos Campos, SP, Brazil) were used in this study. The implants were $10 \mathrm{~mm}$ in length and $3.75 \mathrm{~mm}$ in outer diameter. Twenty-four implants were left machined (as received from the manufacturer), and served as controls (machined - MS). The remaining 24 implants had their surface modified by a laser ablation process (laser modified surface - LMS).

The implants were taken directly from the sterile package, without any additional preparation prior to laser treatment.

The laser treatment was carried out with $1,064 \mathrm{~nm}$ wavelength $(\lambda)$ irradiation, at a pulse frequency of 20 to $35 \mathrm{kHz}(v)$, scanning speed ranging between 80 and $300 \mathrm{~mm} / \mathrm{s}$, scanning space from 0.1 to $0.2 \mathrm{~mm} / \mathrm{s}$, laser pulses interval between $300 \mathrm{~ns}$, and energy from 90 to $100 \mathrm{~mJ} /$ pulse using a pulsed Nd:YAG laser (DigiLaser - DML-100, Violino 10; Laservall $^{\odot}$, Sesto Calende, Valencia, Italy). After treatment, the implants were sent to the manufacturer (AS Technology, São José dos Campos, SP, Brazil) to be cleaned, sterilized and packaged.

\section{Surface characterization}

Topographic evaluation was performed under SEM (LEO 440 - Zeiss, Oberkochen, Germany) to compare the surface morphology of laser-treated versus machined implants. To evaluate the surfaces chemical composition, an energy dispersive analysis of X-ray spectroscopy (EDS - LEO 440, Zeiss, Oberkochen, Germany) was used.

The average roughness $\mathrm{R}_{\mathrm{a}}$ (the arithmetic mean of the sampling area roughness, measured in $\mu \mathrm{m}$ ) of each surface was analyzed using a digital profilometer (Mitutoyo SJ-301, Mitutoyo Sul Americana Ltda., Suzano, SP, Brazil).

\section{Animal selection}

Twenty-four New Zealand white rabbits, 9 to 12 months old $(3,500$ to $4,500 \mathrm{~g})$, were used in the study. The animals were kept in individual cages, fed with a standard laboratory diet, and given tap water ad libitum. The experiment was approved by the Animal Experimentation Committee, School of Dentistry of Araraquara, Araraquara, SP, Brazil.

\section{Experimental design}

A total of 48 implants $(3.75 \times 10 \mathrm{~mm}), 24$ of each kind of surface treatment, were placed in the rabbit tibias (24 animals), and evaluated after 4, 8 and 12 weeks of healing.

\section{Surgical procedures}

The animals were anesthetized through intramuscular injection of a combination of ketamine (Ketamina Agener ${ }^{\circledR}$; Agener União Ltda., São Pau- 
lo, SP, Brazil) $(0.35 \mathrm{mg} / \mathrm{kg}$ of body weight $)$ and $\mathrm{xy}-$ lazine (Rompum ${ }^{\circledR}$ Bayer S.A. São Paulo, SP, Brazil) $(0.5 \mathrm{mg} / \mathrm{kg}$ of body weight). The region of the tibial metaphysis was cleaned with iodine surgical soap. Incisions of approximately $3 \mathrm{~cm}$ in length were performed bilaterally on the internal side of the hind leg, just below the knee. After dissection, the bone surface of the tibial metaphysis was exposed. Bicortical implant beds were prepared using a progressive sequence of spiral drills under saline cooling. One implant $(10 \mathrm{~mm}$ in length and $3.75 \mathrm{~mm}$ in diameter) of each kind of surface treatment was placed in each tibia near the knee joint. The soft tissues were sutured in separate layers and the animals received postoperatively a single intramuscular dose of antibiotic (Pentabiótico Pequeno Porte - Fort Dodge ${ }^{\circledR}$, Campinas, SP, Brazil) $(0.1 \mathrm{ml} / \mathrm{kg}$ of body weight).

\section{Removal torque test}

The animals were killed according to the experimental periods (4, 8 and 12 weeks) with an intramuscular lethal dose of $30 \%$ chloral hydrate $(2 \mathrm{ml} /$ $\mathrm{kg})$. After implant exposure, a specially designed key was connected to both the implant and the manual torque gauge manometer (15-BTG, Tohnichi, Tokyo, Japan). An anti-clockwise movement was performed to remove the implant. The maximal torque value for breakage of bone-implant interaction was measured in Newton centimeters $(\mathrm{N} \mathrm{cm})$. No forces were applied in the vertical direction so as to avoid alterations in the data.

\section{Statistical analysis}

The values of the removal torque were parametric (tested by the Shapiro-Wilk test), and the analysis of the differences between the groups and the different experimental periods in the same group were tested by the ANOVA test, followed by the Bonferroni multiple comparison test $(\mathrm{p}<0.05)$. The roughness analysis was evaluated by the $t$-test.

\section{Results \\ Topographic (SEM) and chemical (EDS) evaluation}

Scanning electron micrographs of the lasertreated and machined surfaces demonstrated micro- scopic differences in the surface topography. SEM surfaces are seen in Figures 1-4. Laser etching created a deep and regular morphological pattern with small pores, while the machined treatment created the typical microscopically grooved and relatively smooth surface characteristic.

The surface micro-topography analysis showed a statistical difference $(\mathrm{p}<0.01)$ between the roughness of the LMS $\left(R_{a}=1.38 \pm 0.23 \mu \mathrm{m}\right)$ and that of the MS $\left(R_{a}=0.33 \pm 0.06 \mu \mathrm{m}\right)$.

The EDS analysis showed no contamination on the machined implants, whereas the same condition was observed on the laser-treated implants; on the latter, the presence of a great amount of oxygen on the surface from the melting and fast cooling process that occurs after surface irradiation was also detected (Graphs 1-2).

\section{Removal torque measurements}

In general, the animals presented no disturbances in soft tissue healing or tibia fractures. The torque measurement yielded statistically significant differences between the machined and the laseretched group $(\mathrm{p}<0.05)$ in all periods of evaluation. The mean and standard deviation of removal torque by group and time period of evaluation are summarized in Table 1.

The highest removal torque corresponded to the laser modified implants, while the lowest was demonstrated by the machined implants (Graph 3).

\section{Discussion}

The resistance of implants to removal torque has been correlated with the degree of bone in contact with the implant by several studies, ${ }^{14-16}$ which associated the changes in the biomechanical characteristics of the interface to the dynamics of bone healing and remodeling process. ${ }^{17-20}$ Although an histological analysis, as the "gold-standard" evaluation procedure for osseointegration, allows visualization of the bone-implant interface, undecalcified histology is able to provide just few sections of each specimen, usually no more than two, to be representative of the implant. Furthermore, an analysis by removal torque, even though in an indirect way, allows a three-dimensional evaluation of the bone-implant 


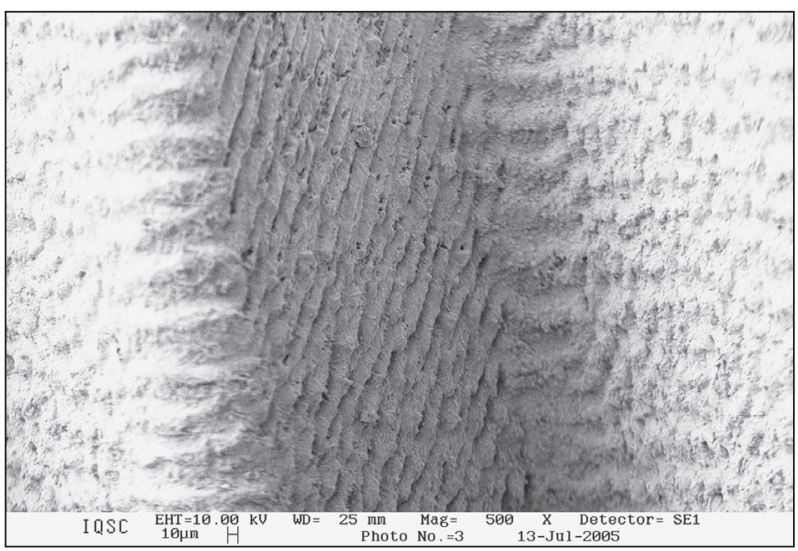

Figure 1 - SEM micrographs of the implants after laser treatment, with original magnification of $500 \mathrm{X}$.

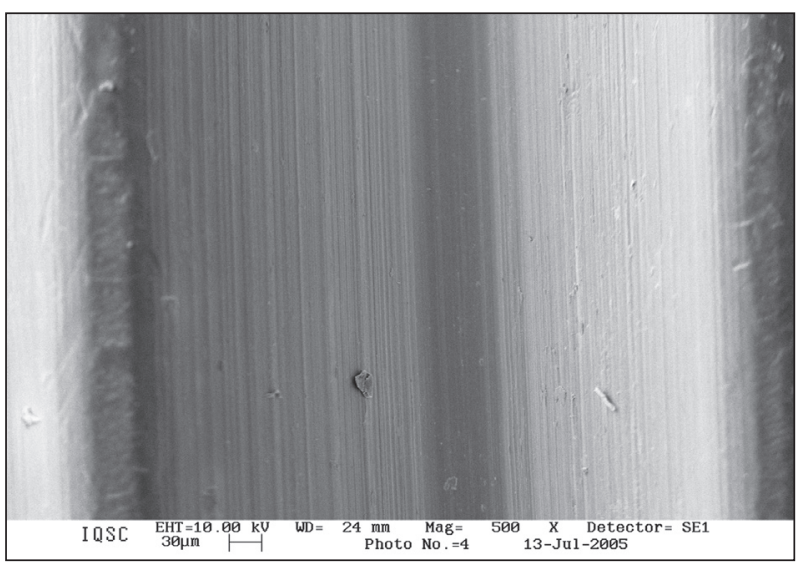

Figure 3 - SEM micrographs of the implants with machined surface, original magnification of $500 \mathrm{X}$.

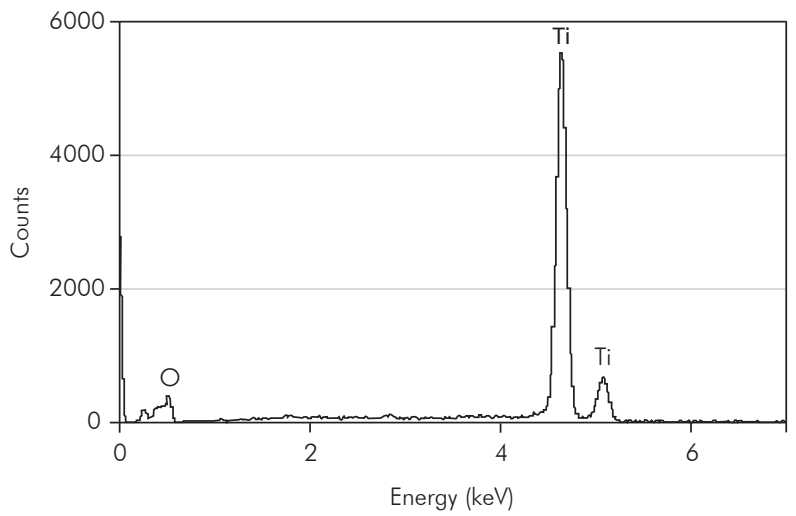

Graph 1 - EDS analysis of a machined surface with predominantly Ti peaks.

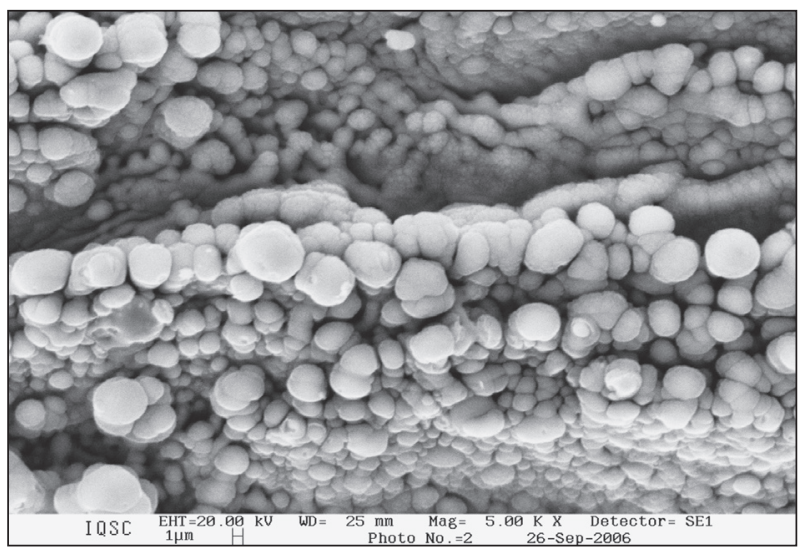

Figure 2 - SEM micrographs of the implants after laser treatment, with original magnification of $5,000 \mathrm{X}$.

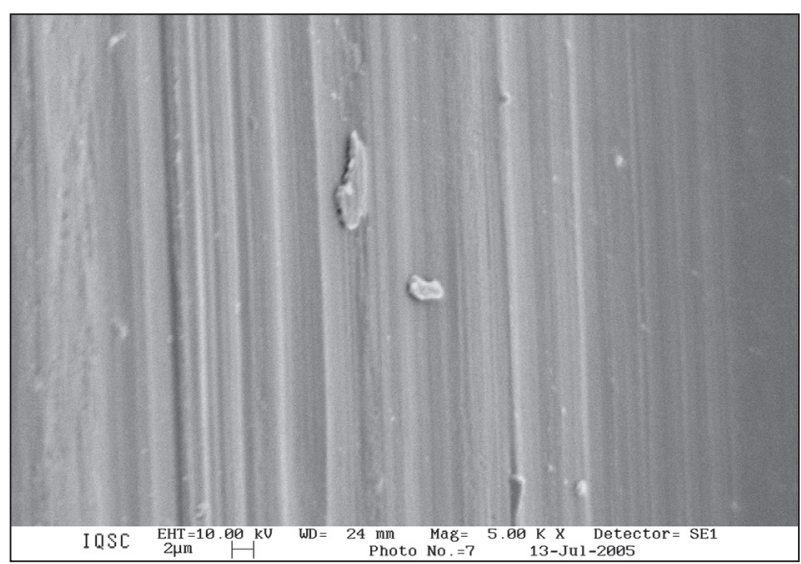

Figure 4 - SEM micrographs of the implants with machined surface, original magnification of $5,000 \mathrm{X}$.

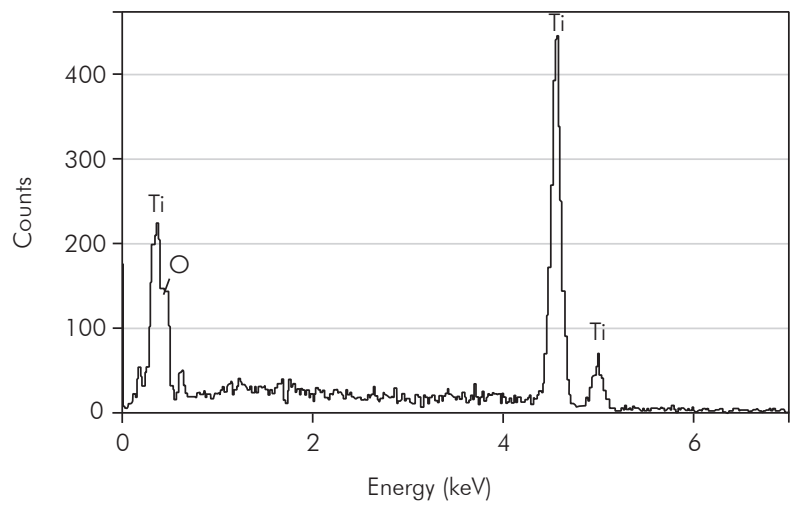

Graph 2 - EDS analysis of a laser-treated implant showing a clean surface with $\mathrm{Ti}$ and $\mathrm{O}$ peaks. 
Table 1 - Mean and Standard Deviation (SD) of removal torque $(\mathrm{Ncm})$ by group and time period.

\begin{tabular}{c|c|c|c}
\hline \multirow{2}{*}{$\begin{array}{c}\text { Periods } \\
\text { (Weeks) }\end{array}$} & \multicolumn{3}{|c}{ Surfaces Evaluated } \\
\cline { 2 - 4 } & MS & LMS & $P$ value \\
\hline 4 & $23.28 \pm 4.46$ & $33.0 \pm 5.8$ & $<0.05^{*}$ \\
\hline 8 & $24.0 \pm 6.34$ & $39.87 \pm 9.58$ & $<0.05^{*}$ \\
\hline 12 & $33.85 \pm 6.28$ & $54.57 \pm 17.73$ & $<0.05^{*}$ \\
\hline
\end{tabular}

*significant difference at $P<0.05$, ANOVA - Bonferroni test.

interface in the whole implant perimeter, and is considered in the literature as an important tool for the evaluation of the osseointegration process. ${ }^{20-24}$

The present study showed that the laser-treated group achieved higher removal torque values when compared to the machined control group. Moreover, the results suggest that the machined implants had a time-dependant anchorage, while the laser-treated implants had an acceleration of this process. Thus, it is possible that the stronger bone integration with laser grooved surfaces observed in the current study is not only due to a rougher surface, but may also be due to a more favorable surface chemistry than that of the machined surface.

Through the SEM analysis, it could be observed that the titanium laser ablation resulted in a very complex surface morphology, enlarging the boneimplant contact interface. The EDS showed that the laser ablation kept the surface purity with a great amount of oxygen, probably due to an increase in the thickness of the surface oxide layer, as already reported, ${ }^{10,25}$ favoring bone integration.

The implant surface properties have a direct role in osteogenesis at the bone-implant interface, influencing a series of coordinated events, including protein adsorption, cell proliferation, and bone tissue deposition. ${ }^{26-28}$

Some in-vivo and in-vitro experiments evaluated the biological comportment of laser modified implants. Soboyejo et al. ${ }^{13}$ (2002) evaluating the cellular response of laser grooved titanium substrates observed that this surface orientated bone cells attachment and inhibited fibroblast growth and migration. Frenkel et al. ${ }^{12}$ (2002) analyzed the effect of laser grooves in a chamber simulating an intramedullary bone response around joint implants and

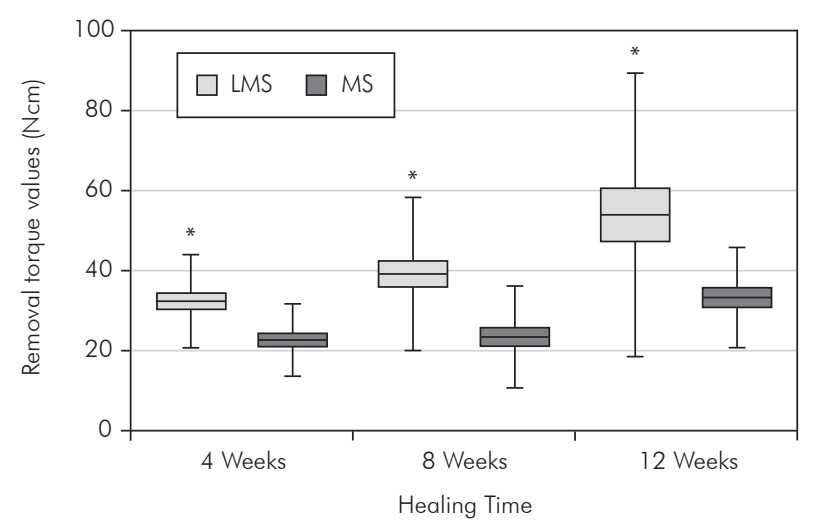

Graph 3 - Distribution of removal torque values ( $\mathrm{Ncm}$ ) for MS and LMS according to the experimental periods (weeks). ${ }^{*}$ significant difference at $\mathrm{P}<0.05, \mathrm{ANOVA}$ - Bonferroni test.

concluded that this surface treatment may induce rapid ingrowth and a strong bone-implant interface, contributing to implant longevity. The same was observed by Li et al. ${ }^{29}$ (1997) by means of an histologic evaluation and a push-out test. They observed that the bone formation into the grooves increased the retention of the implants.

The removal torque values obtained in this study are consistent with the results from previous studies, which have shown a significant increase in bone retention of implants with laser surface modification. Karacs et al. ${ }^{30}$ (2003) compared the removal torque of implants with machined, sand-blasted and sandblasted associated to laser ablation surfaces. They observed that the laser treatment after sand-blasting increased removal torque by almost $50 \%$.

Hallgren et al. ${ }^{9}$ (2003), using a Nd:YAG laser, found a bone-implant contact percentage of $40 \%$ for the laser-modified implants and $32 \%$ for the machined ones. The removal torque test showed a mean value of $52 \mathrm{Ncm}$ for the laser-treated implants and $35 \mathrm{Ncm}$ for the machined implants after 12 weeks of healing. These values were similar to those observed in the present study $(54.57 \mathrm{Ncm}$ and $33.85 \mathrm{Ncm}$, respectively), using the same kind of laser. Similar comportment was found by Cho, Jung ${ }^{3}$ (2003). They compared, by the removal torque test, the implants with machined and laser-modified surfaces after 8 weeks of implantation. The removal torque value was $23.58 \pm 3.71 \mathrm{Ncm}$ for the machined implants and $62.57 \pm 10.44 \mathrm{Ncm}$ for the la- 
ser-modified implants.

As observed and described by different studies, laser treatment seems to be a promising method for dental implant surface modification, producing a surface pattern with important properties for osseointegration, thus improving bone-implant retention, and resulting in a better and faster integration when compared to controls.

\section{Conclusion}

Within the limitations of the present study, the results show that the implants with surfaces modi-

\section{References}

1. Orsini G, Piattelli M, Scarano A, Petrone G, Kenealy J, Piattelli A et al. Randomized, controlled histologic and histomorphometric evaluation of implants with nanometer-scale calcium phosphate added to the dual acid-etched surface in the human posterior maxilla. J Periodontol. 2007 Feb;78(2):209-18.

2. Sakakura CE, Margonar R, Holzhausen M, Nociti Jr FH, Alba Jr RC, Marcantonio Jr E. Influence of cyclosporin-a therapy on bone healing around titanium implants. A histometric and biomechanic study in rabbits. J Periodontol. 2003 Jul;74(7):976-81.

3. Cho SA, Jung SK. A removal torque of the laser-treated titanium implants in rabbit tibia. Biomaterials. 2003 Nov;24(26):485963.

4. Gotfredsen K, Berglundh T, Lindhe J. Bone reactions adjacent to titanium implants with different surface characteristics subjected to static load. A study in the dog (II). Clin Oral Implants Res. 2001 Jun;12(3):196-201.

5. Torensma R, Ter Brugge PJ, Jansen JA, Figdor CG. Ceramic hydroxyapatite coating on titanium implants drives selective bone marrow stromal cell adhesion. Clin Oral Implants Res. 2003 Oct;14(5):569-77.

6. Trisi P, Lazzara R, Rebaudi A, Rao W, Testori T, Porter S. Bone-implant contact on machined and dual acid-etched surfaces after 2 months of healing in the human maxilla. J Periodontol. 2003;74(7):945-56.

7. Buser D, Mericske-Stern R, Bernard JP, Behneke A, Behneke $\mathrm{N}$, Hirt HP et al. Long-term evaluation of non-submerged ITI implants. Part I. 8-year life table analysis of a prospective multi-center study with 2359 implants. Clin Oral Implants Res. 1997 Jun;8(3):161-72.

8. Gaggl A, Schultes G, Muller WD, Karcher H. Scanning electron microscopical analysis of laser-treated titanium implant surfaces - a comparative study. Biomaterials. 2000 May;21(10):1067-73.

9. Hallgren C, Reimers H, Chakarov D, Gold J, Wennerberg A. An in vivo study of bone response to implants topographi- fied by laser ablation produced a significant enhancement in removal torque when compared to the implants with machined surfaces. Further studies are required to evaluate the behavior of these implant surfaces in terms of osseointegration with a histomorphometric analysis.

\section{Acknowledgments}

The authors greatly appreciated the assistance of AS Technology and Aditek-Brazil for the technical support.

cally modified by laser micromachining. Biomaterials. 2003 Feb;24(5):701-10.

10. Bereznai M, Pelsoczi I, Toth Z, Turzo K, Radnai M, Bor Z et al. Surface modifications induced by ns and sub-ps excimer laser pulses on titanium implant material. Biomaterials. 2003 Oct;24(23):4197-203.

11. Cooper LF. A role for surface topography in creating and maintaining bone at titanium endosseous implants. J Prosthet Dent. 2000 Nov;84(5):522-34.

12. Frenkel SR, Simon J, Alexander H, Dennis M, Ricci JL. Osseointegration on metallic implant surfaces: effects of microgeometry and growth factor treatment. J Biomed Mater Res. 2002;63(6):706-13.

13. Soboyejo WO, Nemetski B, Allameh S, Marcantonio N, Mercer C, Ricci J. Interactions between MC3T3-E1 cells and textured Ti6Al4V surfaces. J Biomed Mater Res. 2002 Oct;62(1):56-72.

14. Gotfredsen K, Nimb L, Hjörting-Hansen E, Jensen JS, Holmén A. Histomorphometric and removal torque analysis for $\mathrm{TiO}_{2}$-blasted titanium implants. An experimental study on dogs. Clin Oral Implants Res. 1992 Jun;3(2):77-84.

15. Klokkevold PR, Nishimura RD, Adachi M, Caputo A. Osseointegration enhanced by chemical etching of the titanium surface. A torque removal study in the rabbit. Clin Oral Implants Res. 1997 Dec;8(6):442-7.

16. Wennerberg A, Ektessabi A, Albrektsson T, Johansson C, Andersson B. A 1-year follow-up of implants of differing surface roughness placed in rabbit bone. Int J Oral Maxillofac Implants. 1997 Jul-Aug;12(4):486-94.

17. Carlsson L, Rostlund T, Albrektsson B, Albrektsson T. Removal torques for polished and rough titanium implants. Int J Oral Maxillofac Implants. 1988 Spring;3(1):21-4.

18. Cordioli G, Majzoub Z, Piattelli A, Scarano A. Removal torque and histomorphometric investigation of 4 different titanium surfaces: an experimental study in the rabbit tibia. Int J Oral Maxillofac Implants. 2000 Sep-Oct;15(5):668-74. 
19. Ferguson SJ, Broggini N, Wieland M, de Wild M, Rupp F, Geis-Gerstorfer $\mathrm{J}$ et al. Biomechanical evaluation of the interfacial strength of a chemically modified sandblasted and acid-etched titanium surface. J Biomed Mater Res A. 2006 Aug;78(2):291-7.

20. Johansson C, Albrektsson T. Integration of screw implants in the rabbit: a 1-year follow-up of removal torque of titanium implants. Int J Oral Maxillofac Implants. 1987 Spring;2(2):6975.

21. Baker D, London RM, O’Neal R. Rate of pull-out strength gain of dual-etched titanium implants: a comparative study in rabbits. Int J Oral Maxillofac Implants. 1999 Sep-Oct;14(5):7228.

22. Favero LG, Pisoni A, Paganelli C. Removal torque of osseointegrated mini-implants: an in vivo evaluation. Eur J Orthod. 2007 Oct;29(5):443-8.

23. Margonar R, Sakakura CE, Holzhausen M, Pepato MT, Alba $\mathrm{RC}$, Marcantonio Jr E. The influence of diabetes mellitus and insulin therapy on biomechanical retention around dental implants: a study in rabbits. Implant Dent. 2003;12(4):333-9.

24. Wennerberg A, Albrektsson T, Andersson B, Krol JJ. A histomorphometric and removal torque study of screw-shaped titanium implants with three different surface topographies. Clin Oral Implants Res. 1995 Mar;6(1):24-30.

25. Pérez del Pino A, Serra P, Morenza JL. Oxidation of titanium Through Nd:YAG laser irradiation. Appl Surf Sci. 2002;197(198):887-90.

26. Davies JE. Mechanisms of endosseous integration. Int J Prosthodont. 1998 Sep-Oct;11(5):391-401.

27. Schneirder GB, Zaharias R, Seabold D, Keller J, Stanford C. Differentiation of preosteoblasts is affected by implant surface microtopographies. J Biomed Mater Res A. 2004 Jun;69(3):462-8.

28. Shibli JA, Grassi S, De Figueiredo LC, Feres M, Marcantonio Jr E, Iezzi G et al. Influence of implant surface topography on early osseointegration: a histological study in human jaws. J Biomed Mater Res B Appl Biomater. 2007 Feb;80(2):377-85.

29. Li J, Liao H, Fartash B, Hermansson L, Johnsson T. Surface-dimpled commercially pure titanium implant and bone ingrowth. Biomaterials 1997. May;18(9):691-6.

30. Karacs A, Fancsaly AJ, Divinyi T, Petó G, Kovách G. Morphological and animal study of titanium dental implant surface induced by blasting and high intensity pulsed Nd-glass laser. Mat Sci Eng C. 2003;23(3):431-5. 